\title{
Development of cereal bar with baru almonds and pineaplle peels
}

\author{
Desenvolvimento de barra de cereal com amêndoas de baru e casca de abacaxi \\ Elaboración de barra de cereal con almendra baru y piel de piña
}

Received: 04/05/2021 | Reviewed: 04/15/2021 | Accept: 04/20/2021 | Published: 05/04/2021

Luciano Carlos de Arruda

ORCID: https://orcid.org/0000-0003-3989-8332

Federal University of Mato Grosso, Brazil

E-mail: lucianoarruda28@gmail.com

Wanessa Costa Silva Faria

ORCID: https://orcid.org/0000-0003-1656-5498

Federal Institute of Education, Science and Technology of Mato Grosso, Brazil

E-mail: nessacsf@yahoo.com.br

Nágela Farias Magave Picanço Siqueira

ORCID: https://orcid.org/0000-0003-0187-8256

Federal Institute of Education, Science and Technology of Mato Grosso, Brazil

E-mail: nagela.picanco@blv.ifmt.edu.br

Mayra Fernanda de Souza Campos

ORCID: https://orcid.org/0000-0002-1823-8151

Federal Institute of Education, Science and Technology of Mato Grosso, Brazil

E-mail: mayra.campos@blv.ifmt.edu.br

Wander Miguel de Barros

ORCID: https://orcid.org/0000-0001-5909-7757

Federal Institute of Education, Science and Technology of Mato Grosso, Brazil

E-mail: wander.barros@blv.ifmt.edu.br

\begin{abstract}
Cereal bars have gained constantly growing interests because of their nutritional quality and practicality in consumption. To meet the increasing market needs, their formulation strategies are evolving with each passing day. Therefore, the present study aimed to develop a new formulation of cereal bars with baru almonds and pineapple peels, an agricultural waste, added in different quantities, or be 5.5\% F1, 8.5\% F2, and 9.5\% F3. The developed bars were characterised for microbiological quality, sensory acceptability, and physico-chemical properties. The microbiological analysis identifying $<10 \mathrm{CFU} / \mathrm{g}$ of molds and yeasts on the bars indicated their suitability for human consumption. Further, their sensory evaluation revealed good acceptability and purchase intentions. The three formulations - F1, F2, and F3 - evaluated here were not significantly different; however, the average percentage of the acceptability index attributes of each formulation identified F2 as the best formulation. Subsequent physico-chemical analysis of F2 revealed the nutritional potential of the prepared bars with $50.1 \%$ carbohydrates, $3.44 \%$ fibres, $12.24 \%$ proteins and $19.25 \%$ lipids. Overall, these findings demonstrated that the improved nutrient composition of the prepared cereal bars is attributed to baru almonds and pineapple peels. This study paved the way for utilising industrial wastes and escalating the use of native fruits of Brazil to develop nutrient-rich convenient foods.
\end{abstract}

Keywords: Sensory acceptability; Physico-chemical analysis; Baru almonds; Pineapple peel.

\section{Resumo}

As barras de cereais têm atingido constante crescimento devido à qualidade nutricional e praticidade no consumo. Para atender às crescentes necessidades do mercado, as estratégias de formulação deste alimento estão evoluindo a cada dia que passa. Por isso, o presente estudo teve como objetivo desenvolver uma nova formulação de barras de cereal com amêndoas baru e cascas de abacaxi, um co-produto agrícola, adicionadas em diferentes quantidades, ou seja, 5,5\% F1, 8,5\% F2 e 9,5\% F3. As barras desenvolvidas foram caracterizadas para qualidade microbiológica, aceitabilidade sensorial e propriedades físico-químicas. Pela análise microbiológica foram identificadas $<10 \mathrm{UFC} / \mathrm{g}$ de bolores e leveduras nas barras, indicando adequação higiênico-sanitária para consumo humano. Além disso, a avaliação sensorial revelou boa aceitabilidade e $84 \%$ de intenções de compra entre os provadores. As três formulações - F1, F2 e F3 - avaliadas aqui não foram significativamente diferentes; no entanto, a porcentagem média dos atributos do índice de aceitabilidade de cada formulação identificou F2 como a melhor formulação. A análise físico-química subsequente da F2 revelou o potencial nutricional das barras preparadas com 50,1\% de carboidratos, $3,44 \%$ de fibras, $12,24 \%$ de proteínas e $19,25 \%$ lipídios. No geral, esses achados demonstraram que a melhor composição de nutrientes das barras de cereal preparadas é atribuída às amêndoas baru e cascas de abacaxi. Este estudo abriu caminho para a utilização de co-produtos industriais e a escalada do uso de frutas nativas do Brasil para desenvolver alimentos convenientes ricos em nutrientes.

Palavras-chave: Aceitabilidade sensorial; Formulação; Análise físico-química; Amêndoas de baru; Casca de abacaxi. 


\section{Resumen}

Las barras de cereales han ganado un interés en constante crecimiento debido a su calidad nutricional y practicidad en el consumo. Para satisfacer las crecientes necesidades del mercado, sus estrategias de formulación evolucionan día a día. Por tanto, el presente estudio tuvo como objetivo desarrollar una nueva formulación de barritas de cereales con almendras baru y cáscaras de piña añadidas en diferentes cantidades. Las barras desarrolladas se caracterizaron por su calidad microbiológica, aceptabilidad sensorial y propiedades físico-químicas. El análisis microbiológico que identificó < 10 UFC / g de mohos y levaduras en las barras indicó su idoneidad para el consumo humano. Además, su evaluación sensorial reveló buena aceptabilidad e intenciones de compra. Las tres formulaciones - F1, F2 y F3 evaluadas aquí no fueron significativamente diferentes; sin embargo, el porcentaje promedio de los atributos del índice de aceptabilidad de cada formulación identificó a F2 como la mejor formulación. El análisis físico-químico posterior de F2 reveló el potencial nutricional de las barras preparadas con 50,1\% de carbohidratos, 3,44\% de fibras, 12,24\% de proteínas y 19,25\% de lípidos. En general, estos hallazgos demostraron que la composición mejorada de nutrientes de las barras de cereales preparadas se atribuye a las almendras baru y las cáscaras de piña. Este estudio allanó el camino para la utilización de desechos industriales y la intensificación del uso de frutas nativas de Brasil para desarrollar alimentos convenientes ricos en nutrientes.

Palabras clave: Aceptabilidad sensorial; Formulación; Análisis físico-químico; Almendras baru; Cáscara de piña.

\section{Introduction}

Worldwide, the increasing incidence of morbidities like obesity, diabetes, malnutrition, heart disease, etc., has increased the demand for balanced, safe, and healthy diets. In addition, the busy and changing lifestyles, rapid urbanisation, and increased income of people have escalated the consumption of healthy and ready-to-eat convenient foods (Freitas, 2005). Pertaining to this, cereal bars, made from the extrusion of cereal mass, with a sweet and pleasant taste (Izzo et al., 2001) have gained growing interest. The ready-to-eat food bars rich in nutrients, such as vitamins, minerals, proteins, complex carbohydrates, and dietary fibres (Marques et al., 2015) are used as a quick and healthy snack option, replacing the traditional snacks that are rich in sodium and lipids, whose excessive consumption can contribute to the development of chronic diseases (Sarantópoulos et al., 2001), as well as the consumption of sweets without nutritional value (Skliutas, 2002). The cereal bars are formulated by compressing the healthy cereals, dried fruits or nuts, flavour agents, and suitable binding agents that complement each other in terms of taste, texture, and physic-chemical properties. The ingredients of the cereal bar, including the cereal base, and the other ingredients vary unless it compromises the quality of the product (Gutkoski et al., 2007; Paiva et al., 2012), depending on the need of the consumers. Furthermore, the added fruits, dehydrated seeds, processed vegetables enrich the bars with nutrients such as lipids, fibre, protein, minerals, and vitamins highlights the interest in fruits from Cerrado among farmers, traders, industries, research and technical assistance institutions, cooperatives, universities, health and food agencies, among others (Guimarães et al., 2008). Moreover, cereal bars facilitate the use of regional fruits and increase their industrial acceptability in the form of bars that are convenient and nutrient-rich food alternatives (Lima et al., 2010).

Among the native fruits of the Cerrado, baru (Dipteryx alata) presents an economic potential and has a great acceptance for its pleasant taste, similar to peanuts (Sano et al., 2004). It is popularly known as cumbaru, coumaru, coco-beans, barujó, and iron chestnut (Bozza, 2004). The barueiro is a large tree legume (15 m to $25 \mathrm{~m}$ in height), which bears fruit between August and October (Lima et al., 2010). The pulp is consumed in natura, toasted (Togashi \& Sgarbieri, 1995), and in the form of sweets, jams, peanuts, paçoquinha, brown sugar, panettone, cereal bar, breakfast cereals, cakes, cookies, breads, bonbons, etc. Baru almonds have a great potential to substitute cashew nuts and walnuts equivalently, being an interesting alternative (Freitas \& Naves, 2010). It can be served in restaurants and, in the future, it can also be exported to the foreign market, creating a large consumer base for nuts (Ávila et al., 2010). In addition, its seed (almond) has a high nutritional value, containing $23-30 \%$ of protein, and $40 \%$ of lipids (Freitas \& Naves, 2010). Baru almond is also a source of minerals, especially calcium, iron, and zinc (Fernandes et al., 2010; Freitas \& Naves, 2010; Takemoto et al., 2001).

Brazil is the world's third largest producer of fresh fruit and the largest pineapple producer in South America. Pineapple is a plant, edible and highly industrialized, of which only $22.5 \%$ correspond to the pulp of the fruit. Of the remaining 
$77.5 \%$, the bark contributes $4.5 \%$, and the vegetative part contributed $73 \%$. It is also known that during the processing of fruits, food agro-industries generate a large amount of residues with high nutritional value that are mostly discarded as peels, stalks and bagasse, imposing a growing problem (Kobori, 2005; Oliveira et al., 2002). Therefore, the proper management of these wastes has become a major concern in the food industry. Moreover, the industrial residues of this fruit comprising the bark and central cylinder have been little studied (Botelho et al., 2002). The processing of pineapple with appropriate techniques generates several by-products, which could be utilised to produce many value-added products. For instance, Costa et al. (2007), suggested the production of a powder with high fibre content, good protein quantity and high concentrations of vitamin $\mathrm{C}$, from the bagasse and the pineapple peel could be used in food enrichment. Furthermore, Botelho et al. (2002) conducted a study to verify the composition of dietary fibre present in pineapple peel and central cylinder and concluded that both can be considered a good source of insoluble fibre (cellulose, hemicellulose, and lignin), but are poor in soluble fibre, such as pectin. Moreover, the bark also contained higher insoluble and soluble fibre (lignin, cellulose, hemicellulose and pectin). Therefore, the proper management of these residues as a valuable resource could improve the technological and nutritional quality of the final product while reducing the impacts on the environment (Fonseca et al., 2011). For instance, the formulation of cereal bars utilising these resources could allow the diversification of products to valuable nutritional food products.

Therefore, the present study was aimed to develop new formulations for the development of nutrient-rich cereal bars using different quantities of baru almonds and pineapple peels.

\section{Methodology}

\subsection{Raw ingredients and processing of baru almonds and pineapple peels}

The cereal bars were prepared using the mixture of baru almonds with dehydrated pineapple peel. The dehydrated almonds were supplied by COMPRUP (Mixed Cooperative of Rural Producers) located in the Municipality of Poconé/MT and pineapples were obtained from the fairs in the Region of Cuiabá/MT. The other ingredients-Harald rice flakes® (São Paulo, Brazil), Jasminese ${ }^{\circledR}$ (Paraná, Brazil), refined sodium Cisne® (Cabo-Frio, Brazil), glucose syrup Arcólor® (São Paula, Brazil), jasmine brown sugar ${ }^{\circledR}$ (Paraná, Brazil), Wildflower honey® (Dourados, Brazil), and hydrogenated vegetable fat Vigor Alimentos® (São Caetano do Sul, Brazil)—were acquired in the trade of the city of Cuiabá/MT.

The dehydrated baru almonds were crushed in a processor (WALITA ${ }^{\circledR}$, model RI2035/01) and sieved with a sieve of diameter ranging from 50 to $315 \mu \mathrm{m}$ to obtain the flour. The pineapples after cleaning and sanitizing were peeled manually. The pulp and peel of the fruits were cut and dehydrated in a drying oven with air circulation (MA035/5) at $65^{\circ} \mathrm{C}$ for $24 \mathrm{~h}$. Subsequently, the pineapples (pulp and peel) were cooked on an industrial stove at a temperature of $93^{\circ} \mathrm{C}$ for $1 \mathrm{~h}$.

\subsection{Processing of cereal bars}

The cereal bars based on baru almonds and dehydrated pineapple peel were prepared using $40 \%$ and $60 \%$ agglutinating and dry ingredients, respectively. Three different formulations, F1, F2, and F3, were prepared with 20, 23, and $25 \%$ of baru almonds and 5.5, 8.5, and $9.5 \%$ of dehydrated and cooked pineapple peels, respectively. The compositions of the three formulations are shown in Table 1.

The dry ingredients were heated in a conventional oven (Philco PFE48P) at $100{ }^{\circ} \mathrm{C}$ for $15 \mathrm{~min}$. The agglutinate syrup was then prepared in a stainless-steel container, to which the previously weighed agglutinating ingredients were added, mixed, and heated for $10 \mathrm{~min}$ with stirring. The total soluble solids content was monitored in a manual refractometer until the syrup was obtained with $85-89^{\circ}$ Brix. The prepared syrup was then added to the previously heated dry ingredients at a temperature around $40^{\circ} \mathrm{C}$ until homogeneous incorporation of the syrup into the cereal mixture. After cooling, modeling and lamination were performed in a stainless steel tray to obtain the size and weight os the cereal bar of $10 \mathrm{~g}$ each. 
Table 1. The compositions of the three formulations of the cereal bar prepared with baru almonds and pineapple peels.

\begin{tabular}{lccc}
\hline \multirow{2}{*}{ Agglutinating Ingredients } & \multicolumn{3}{c}{ Formulation $(\mathrm{g} / 100 \mathrm{~g})$} \\
\cline { 2 - 4 } \multicolumn{1}{c}{ Glucose syrup } & $\mathbf{F 1}$ & $\mathbf{F 2}$ & $\mathbf{F 3}$ \\
Brown sugar & 20 & 20 & 20 \\
Honey & 10 & 10 & 10 \\
Vegetable fat & 5 & 5 & 5 \\
\hline Dry ingredients & 5 & 5 & 5 \\
\hline Rice flakes & & & 11 \\
Sesame & 14 & 12 & 11 \\
Baru almonds & 15 & 12 & 25 \\
Dehydrated pineapple pulp & 20 & 23 & 3 \\
Dehydrated and cooked pineapple & 5 & 4 & 9.5 \\
peel & 5.5 & 8.5 & 0.5 \\
NaCl (Table salt) & & & \\
\hline
\end{tabular}

Source: Authors (2021).

\subsection{Analyses}

\subsubsection{Microbiological analyses}

Microbiological analysis of mold and yeast count was performed, according to RDC $\mathrm{N}^{\circ}$. 12, which regulates the Microbiological Standards for Food (Brasil, 2001) following the method described by Silva et al. (2010).

\subsubsection{Affective acceptance and purchase intent test}

This project was submitted and approved by the Human Research Ethics Committee under opinion number 159-137, according to the Resolution 196/96 of the Brazilian National Health Council. The sensory evaluation tests were performed at the Sensory Analysis Laboratory at IFMT - Campus Cuiabá Bela Vista/MT. All participants signed the free and informed consent form (TCLE). Fifty untrained volunteer tasters over 18 years of age of both sexes (all with experiences in cereal bar consumption) were recruited. Samples of the three formulations were presented to the tasters separately, in individualized cabins, under white light, with no noise, and they were instructed to drink the water, which was arranged in the cabin, to clean the palate. The structured hedonic scale of 9 points was used, with an acceptance scale ranging from very disliked (1) to very liked (9) for the attributes, including appearance, aroma, flavour, texture, and Global impression (Stone \& Sidel, 1993). The Acceptability Index (AI) for each preparation was estimated following Teixeira et al. (1987) using the above-mentioned formula; $\mathrm{AI}(\%)=\mathrm{A} \times 100 / \mathrm{B}$, where A was the average score obtained for the product, and B was the maximum score given to the product.

The intention to purchase the tasters in relation to the samples was also evaluated through the following questionnaire;

1. Would you consume cereal bars?

(...) Every day; (...) Every 15 days; (...) Once a week; (...) Once a month.

2. Would you buy the cereal bar you liked the most?

Yes (...) or No (...). 


\subsubsection{Physico-chemical characterisation}

The $\mathrm{pH}$, humidity, ash, ether layer (lipids), and protein content of the cereal bars were estimated according to the procedures of the Adolfo Lutz Institute (Brasil, 2005). The dietary fibre content was determined according to the official method of AOAC (Firestone, 2012; method number 991.43), and the carbohydrate content was estimated by subtracting the sum of proteins, lipids, ash, and dietary fibre contents from 100. All the analyses were done in triplicates.

The following formula (Brasil, 2003) was used to estimate the caloric value based on centesimal composition data using the conversion factors of $4 \mathrm{kcal} / \mathrm{g}$ for carbohydrates and proteins and $9 \mathrm{kcal} / \mathrm{g}$ for lipids;

Total caloric value $=(\%$ of sample lipid $\times 9)+(\%$ of protein sample $+\%$ carbohydrate sample $) \times 4$.

\subsection{Statistical analyses}

The results of sensory acceptability were analysed using the analysis of variance (ANOVA). The means were compared by the Tukey test at 5\% significance level.

\section{Results and Discussion}

\subsection{Microbiological analyses}

The microbiological results of the mold and yeast count for the three cereal bar formulations were $<10 \mathrm{UFC} / \mathrm{g}^{-1}$, which was within the permissible limit $\left(5.0 \times 10^{2} \mathrm{UFC}^{-1}\right)$ of the microbiological standards established for fruits, fruit products and the like (Brazil, 2001). These results indicated the sanitary quality of the formulations at all stages of the production. In RDC $\mathrm{n}^{\circ}$. 12/2001, limits are expressed for thermotolerant coliforms (less than $5 \times 10^{2} \mathrm{UFC} / \mathrm{g}$ ) and mesophiles (less than $5 \times 10^{4} \mathrm{UFC} / \mathrm{g}$ ) in cereal-based products, whereas the limits for molds and yeasts has not yet been outlined.

\subsection{Sensory analysis}

The averages of the scores obtained for the three formulations are shown in Table 2. The high scores (> 6) indicated good acceptability of all the formulation of the cereal bars made with baru almonds and pineapple skin. Moreover, the obtained scores for the three formulations did not differ significantly, suggesting the homogeneity of the formulations F1, F2, and F3 in all attributes.

The purchase intention of a consumer is significantly influenced by the appearance, colour, aroma and flavour attributes of a food product (Aguiar et al., 2008). Here, the appearance of the cereal bars was almost the same, indicating that the different concentrations of baru almonds and pineapple peel did not interfere with the product's visual characteristics. In addition, flavour, the most appreciated attribute in a food product was also consistent with different concentrations of baru almonds in the cereal bar. Further, the overall impression, which represents, mostly, the first impression for a product as a whole, not being biased with the average of the scores of the other characteristics evaluated (Gomes \& Penna, 2009) was also found to be high (7.29-7.58) for all the three formulations (Table 2). 
Table 2. Values of sensory attributes for the sensory acceptance of cereal formulations.

\begin{tabular}{lccc}
\hline \multicolumn{1}{c}{ Attributes } & Formulation (F1) & Formulation (F2) & Formulation (F3) \\
\hline Color & $7.79 \pm 0.15$ & $7.63 \pm 0.17$ & $7.50 \pm 0.17$ \\
Aroma & $7.42 \pm 0.18$ & $7.62 \pm 0.19$ & $7.50 \pm 0.18$ \\
Flavor & $7.21 \pm 0.17$ & $7.52 \pm 0.19$ & $7.44 \pm 0.19$ \\
Texture & $6.77 \pm 0.22$ & $6.87 \pm 0.25$ & $6.33 \pm 0.24$ \\
Global Appearance & $7.48 \pm 0.14$ & $7.58 \pm 0.15$ & $7.29 \pm 0.16$ \\
\hline
\end{tabular}

The mean values indicate that there is no significant difference between the samples $5 \%(\mathrm{p}>0.05)$ by the Turkey test. Source: Authors (2021).

The acceptability indices obtained for the three cereal bar formulations are shown in Table 3 . When developing a new product, one of the fundamental points is to evaluate its acceptability, to predict its behaviour towards the consumer market (Moscatto et al., 2004). Here, the AI for the three formulations ranged from 70.33 to $86.55 \%$, supporting the good acceptability of the formulated cereal bars. These findings were in accordance with earlier studies (Dutcosky 2007; Teixeira et al., 1987), who proposed that the AI of a food product to be considered as accepted should at least be $70 \%$, in terms of its sensory properties. Moreover, Bastos et al. (2014) have reported a similar range of AI for commercial cereal bars with different textures in relation to their flavour and overall impression.

Table 3. Acceptability indices (\%) obtained for the three cereal bar formulations, F1, F2, and F3.

\begin{tabular}{lccc}
\hline \multicolumn{1}{c}{ Attributes } & F1 & F2 & F 3 \\
\hline Color & 86.55 & 84.77 & 83.33 \\
Aroma & 82.44 & 84.66 & 83.33 \\
Flavor & 80.11 & 83.55 & 82.66 \\
Texture & 75.22 & 76.33 & 70.33 \\
Global Appearance & 83.11 & 84.22 & 81.00 \\
\hline
\end{tabular}

Source: Authors (2021).

Cereal bars added with baru almonds complemented with pineapple peel have great market potential, as they obtained satisfactory results in terms of levels of sensory acceptance and consumption intention, as shown in Figure 1. Maximum of the tasters demonstrated a favourable consumption intention for the three samples analysed, in which $84 \%$ of consumers showed their interest to buy the cereal bar and 38\% to consume at least once a month and another $32 \%$ once a week. These results indicated the acceptability of the ingredients used for the formulation of the bars. In accordance, Fonseca et al. (2011) reported a high degree of acceptance of the cereal bars prepared with pineapple peel jelly. The study showed that $67 \%$ of the tasters indicated their interest to certainly buy the new product, $30 \%$ to probably buy, and 3\% to perhaps buy in relation to the purchase rate. The use of agro-industrial waste can be a viable alternative for the development of new products that follow this trend and meet this demand (Bueno et al., 2020). The use of shells and pits can also reduce the waste of tons of food resources that contributes to one of the biggest environmental problems that affects the population today - the excessive production of solid waste (Ramos et al., 2020).

Louredo et al. (2014) reported satisfactory results for acceptability of cookies enriched with baru with 53\% classifying it as excellent for purchase intention, and 51.6\% adhered to consumption. In relation to the acceptance rate of cookies with different concentrations of pineapple dehydrated peel flour prepared by Sousa et al., (2020) also obtained satisfactory results (78.91 to $85.53 \%$ ) between the tasters. In addition, in terms of flavour, texture, and appearance, the breads developed with 
different proportions of baru almonds in place of wheat flour are well accepted (Rocha \& Santiago, 2009). Ávila (2012) produced gluten-free bread using almonds from the Cerrado (baru, bocaiuva, and pequi) and reported that the flavour and general acceptability attributes of breads with baru, and bocaiuva was higher than pequi flour, suggesting the beneficial effects of baru flour in generating a more pleasant taste. In addition, the baru contents also improved the texture acceptability; therefore, the optimal composition of the flours was suggested to be 52\% Baru flour, 23\% Bocaiúva flour, and 24\% Pequi flour. Similarly, the cereal bars formulated by Lima et al. (2010), with $14 \%$ baru almond and $0 \%, 5 \%$, and $10 \%$ baru pulp were well accepted by potential consumers of cereal bars. Although replacing oat brans with baru pulp in the preparation of cereal bars did not influence the acceptability of the product, the modification improved its nutritional value. In addition, Santos et al. (2012) have reported increased acceptability of the paçocas formulated by replacing peanuts with different concentrations of baru almonds $(25 \%, 50 \%$, and $75 \%)$, which was the highest for the formulation with $25 \%$ baru concentration, with an average score $>7$. Taken together, these results demonstrate the favourable acceptance for products made with baru almond.

Figure 1. Consumption intention for the different formulations of cereal bars.

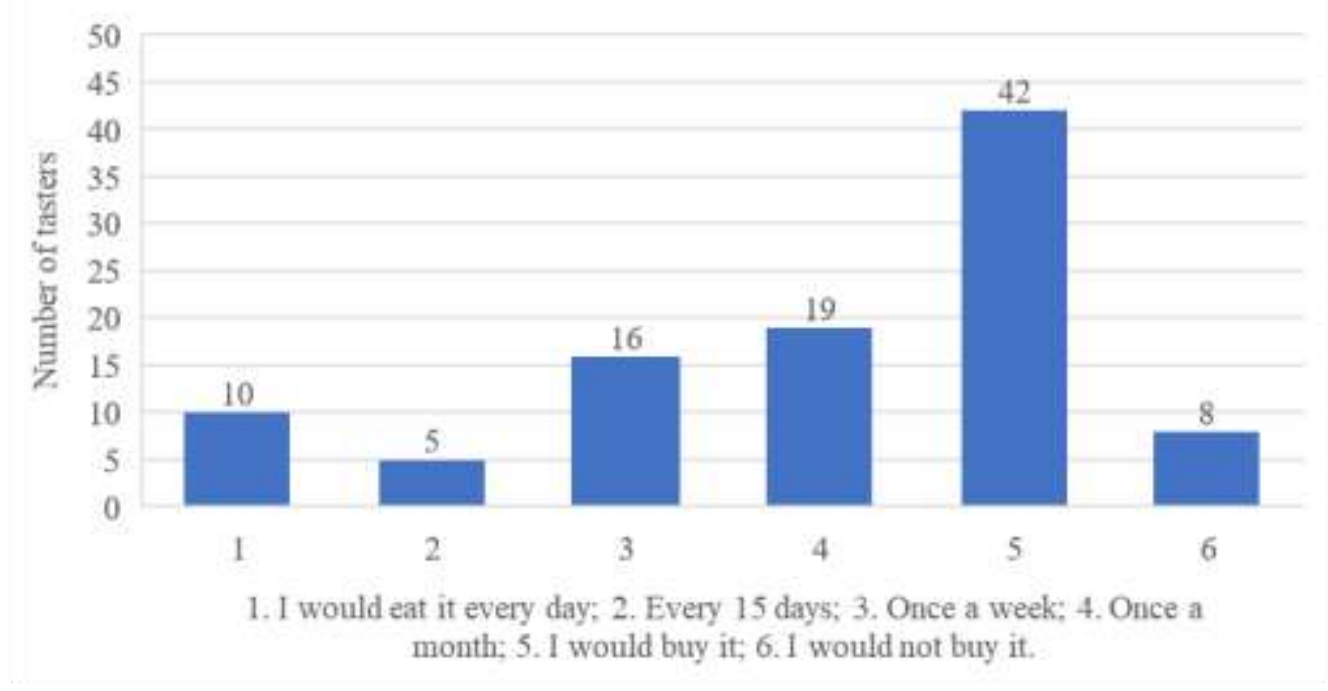

Source: Authors (2021).

The composition of the cereal bars is mostly based on the target consumers and their preferences, and their production and marketing are mostly segment based (Matsuura, 2005). For example, bars containing specific vitamins and minerals are produced for women, the specific composition has also been formulated for the prostate in men, bars to stabilise the blood sugar level in people with diabetes, and bars that help fighting osteoporosis. In addition, Frazier et al. (1993) has reported the formulations to meet the individual's daily energy and growth needs.

\subsection{Physico-chemical analysis}

In the present study, most of the tasters showed a favourable consumption intention for the three formulations analysed, with no statistical difference between them. Therefore, to decide on the choice of the formulation with the best acceptability, we estimated the average percentage of the attributes of the AI of each formulation, which identified F2 (figure 2) as the best-accepted cereal bar with average acceptability of $82.70 \%$. Therefore, we selected F2 for further physical- 
chemical analyses. As shown in Table 4, the proximate composition of the baru almond cereal bar with pineapple peel (F2) revealed higher contents of carbohydrates, lipids, and proteins.

Figure 2. Appearance of the F2 formulation cereal bar.
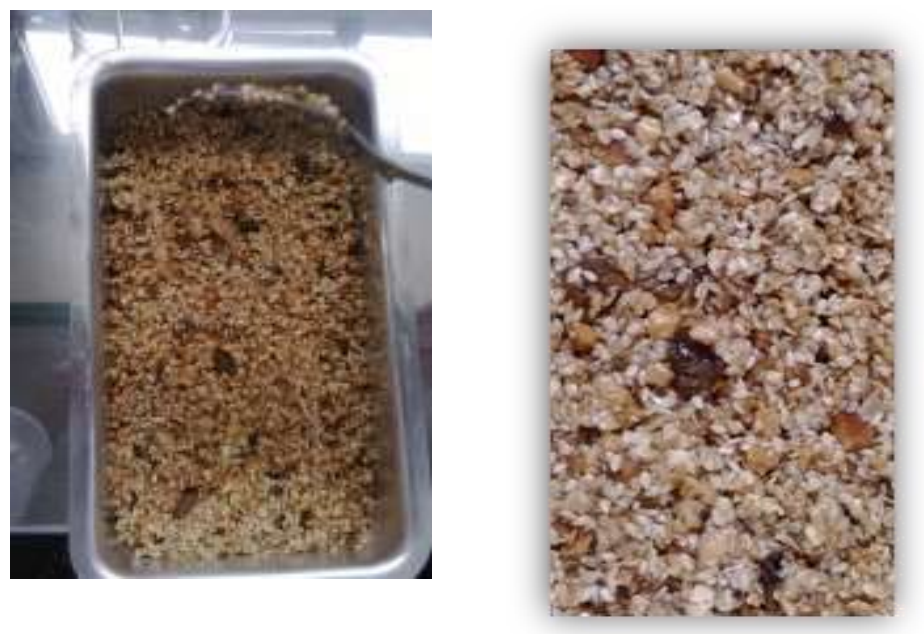

Source: Authors (2021).

Table 4. Average values of the physical-chemical composition of the cereal bar with baru almonds complemented with pineapple peel.

\begin{tabular}{cccccccc}
\hline pH & Moisture \% & Ash \% & Proteins \% & Carbohydrates \% & Fibre \% & Lipids \% & $\begin{array}{c}\text { Caloric } \\
\text { Value kcal }\end{array}$ \\
\hline 5.10 & 11.67 & 3.3 & 12.24 & 50.1 & 3.44 & 19.25 & 422.61 \\
\hline
\end{tabular}

Source: Authors (2021).

The average $\mathrm{pH}$ of $\mathrm{F} 2$ samples was determined to be 5.10, which indicated that the cereal bars were slightly acidic (Jay, 2005). Similar pH values for cereal bars ranging from 5.38 to 6.68 were also reported by previous studies (Arévalo, 2013; Rodrigues, 2011); in contrast, Lima (2012) observed lower $\mathrm{pH}$ of 4.5. Based on the minimum $\mathrm{pH}$ required for the multiplication and production of Clostridium botulinum toxin (4.50) and the multiplication of the vast majority of bacteria (4.00), Jay (2005) classified the foods as slightly acidic ( $\mathrm{pH}>4.50)$, acidic $(\mathrm{pH} 4.00$ to 4.50$)$ and very acidic $(\mathrm{pH}<4.00)$. Therefore, it can be inferred that the slightly acidic conditions of the cereal bars are not conducive for the growth of these food contaminating microbes.

The estimated average humidity of $11.67 \%$ complied with CNNPA Resolution No. 12 of 1978, which demarcated the maximum moisture limit in cereal products as 15\% (Brasil, 1978). Our findings were consistent with several earlier studies reporting similar levels of moisture content for cereal bars containing baru almond (12.0\%, Bueno, 2005; 10.75-13.95\%, Gutkoski, 2007; 9-13\%, Lima et al., 2010; 13.50\%, Souza and Srebernich, 2010) Similarly Loverday et al. (2009) found humidity values between 10 to $15 \%$.

The reduced humidity contributes to the preservation of the technological quality of cereal bars, favouring the maintenance of crispness, a characteristic sensory attribute of the product (Guimarães \& Silva, 2009). According to Takeuchi et al. (2005), crunchiness is synonymous with freshness and product quality, while its loss, characterised by softening, is one of 
the causes of consumption rejection. In addition, low moisture content can prevent non-enzymatic browning as well as protect cereal bars from microbial growth and, therefore, increase the shelf life of the product (Cecchi, 2003).

The ash corresponds to the amount of mineral substances present in food, due to volatilisation losses, caused by the burning of organic matter. These inorganic residues are used as a criterion in the identification and general quality of food (Chaves et al., 2004). The average mineral matter of F2 (3.3\%) was higher than those reported by earlier studies for cereal bars made with baru almonds that ranged from 1.13 to 1.61\% (Brito et al., 2004; Brasil, 2001; Bueno, 2005; Guimarães \& Silva 2009; Lima et al., 2010; Silva et al., 2009). In addition, Freitas \& Moretti (2006) in a study with cereal bars with high protein and vitamin content reported the mineral matter content as $2.2 \%$. From the findings of the present and earlier studies, it can be inferred that the dehydrated pineapple residues with a high content of minerals, (2.03-2.20\%; Costa et al., 2007; Lemos et al., 2010), which might vary dehydrated pineapple peels could have contributed to the higher mineral matter of F2 bars.

The protein content of the cereal bar was $12.24 \%$. In accordance, similar levels of protein contents have been reported by earlier studies-11.33 to 13.27\% (Colussi et al., 2013), 10.23 to 11.23\% (Lima et al., 2010); however, Arévalo et al. (2013) reported a slightly higher protein content (15.25-18.57\%). In contrast, the cereal bars available in the market have a lower protein content of 4.4 to 5.36\% (Bueno, 2005; Monteiro et al., 2006; Sampaio, 2009). Taken together, it is clear that the cereal bars formulated in this study contain markedly higher protein contents, which could be attributed to the supplementation of the bars with baru almonds containing 23 to $30 \%$ protein (Fernandes et al., 2010).

Of all the components, carbohydrate content contributed the highest proportion $(50.10 \%)$, which could be because of the cereal base used to prepare cereal bars. In accordance, Souza et al. (2010) have demonstrated that carbohydrates are the components present in the highest amount in cereal-based foods. Moreover, glucose from corn, honey, and brown sugar used as the agglutinated reagents could also have contributed to the overall carbohydrate content of the cereal bars. In accordance, Lima et al. (2009), though used a different formulation for preparation of cereal bar with baru almonds, they reported a similar level of carbohydrate content. However, several other studies have detected a higher range of carbohydrate contents (60.9780.85\%) in cereal bars (Freitas \& Moretti, 2006; Brito et al., 2004). The observed difference could be attributed to the processing conditions (time and temperature), different ingredients, and their proportions used in the formulation of the cereal bars.

The fibre content representing the non-digestible crude fibre content of the cereal bars was estimated to be $3.44 \%$, which as within the range (3.08-3.44\%) reported by several earlier studies (Brito et al., 2004; Freitas and Moretti, 2006). Moreover, Mesquita (2016), in a flavoured baru snack, detected 3.23\% fibre content, whereas Colussi et al. (2013) found a higher (11.2-19.46\%) crude fibre content in cereal bars based on oats and golden flaxseed. These results indicated that the dry ingredients used for the preparation of the cereal bars determine the fibre content of the cereal bar.

The lipid content in F2 (19.25\%) was higher than that found in commercial cereal bars (11\%; Freitas \& Moretti, 2006), which could be due to the addition of baru almonds with high lipid contents ranging from 40 to $42 \%$ (Lima et al., 2010; Rinaldi et al., 2016), and the addition of hydrogenated vegetable fat and agglutinating ingredients. Sousa et al. (2020) found similar results for lipid concentration (19.81\%) in cookies developed with dehydrated pineapple peel flour. In accordance, similar levels of lipid contents in the food products, including the cereal bars (Lima et al., 2010; Rinaldi et al., 2016), and snack items (Mesquita, 2016) containing baru almonds have been reported. Baru almond is a good energy source (Fernandes et al., 2010; Freitas, 2009; Lima \& Costa, 2009; Togashi \& Sgarbieri, 1994; Vera et al., 2009). In addition, the baru almonds have a healthy fatty acid composition with a $\omega-6$ to $\omega-3$ ratio of 9:1). Diets with a $\omega-6: \omega-3$ ratio of $\sim 10: 1$ have been shown to reduce the risk of developing cardiovascular diseases (Freitas \& Naves, 2010). These results suggest that the cereal nuts prepared with baru almonds could be a source of good quality lipids compared to commercial formulations. 
The barueiro almonds from the Cerrado of Goiás contain $75.58 \%$ (Vera et al., 2009) to $81.20 \%$ (Takemoto et al., $2001)$ unsaturated fatty acid content. The oleic ( $\omega-9)$ acid followed by linoleic $(\omega-6)$ contents contributed the maximum to the total unsaturated fatty acid contents of baru almonds, indicating the baru almonds as a source of good fats. It has been shown that the monounsaturated fatty acids (MUFAs), such as oleic acids, and the polyunsaturated fatty acids (PUFAs)such as linoleic acid (C18: 2), have favourable effects in reducing the serum levels of LDL cholesterol (Fuentes, 1998).

The total caloric value of the cereal bar in a $100 \mathrm{~g}$ serving was $422.61 \mathrm{kcal} / 100 \mathrm{~g}$. In accordance, Colussi et al. (2013) reported the values varying from 324.11 and $421.84 \mathrm{kcal} / 100 \mathrm{~g}$, whereas Cecchi (2003) has reported a slightly lower value of $400 \mathrm{kcal}$. Furthermore, Brito et al. (2004) have shown that the total caloric values of homemade and industrialised cereal bars are lower than those obtained for F2 formulations in this study.

\section{Conclusion}

The present study demonstrated that the prepared cereal bars rich in proteins, carbohydrates, lipids and fibres with good physico-chemical properties could be potential energy sources. In addition, this study also revealed that neither the concentrations of baru almonds nor the dehydrated pineapple peels interfere with the appearance or acceptability of the bars. The findings suggest that the prepared cereal bars are suitable for human consumption because they are free of microbiological contamination; in addition, the best and favourable fatty acid composition of cereal bars with baru almonds and pineapple peels suggest their potential use in the diet plans of obese and/or oncologic patients. Overall, the study recommends using baru as a cerrado fruit and pineapple peel residue from the processing industries to add value to fruit and nutritional quality of the product and contribute to its sustainable use.

\section{References}

Association of Official Analytical Chemists (AOAC). (1970). Official Methods of Analysis, (12th ed.). Association of Official Agricultural Chemists.

Ávila, R., Oliveira, L. F., \& Ascheri, D. P. R. (2010). Caracterização dos Frutos Nativos dos Cerrados: 4 Araticum, Baru e Jatobá. Revista Agrotecnologia 1: 53-69.

Ávila, E. R. L. G. (2012). Utilização de amêndoas de frutos do cerrado na produção de pães sem glúten. Dissertação (Mestrado em Saúde e Desenvolvimento na Região Centro-Oeste de Mato Grosso do Sul) - Universidade Federal de Mato Grosso do Sul, Campo Grande - MS.

Aguiar, L. P., Figueiredo, R. W., Alves, R. E., et al. (2008). Physical and physico-chemical characterization of fruits from different genotypes of bacuri (Platonia insignis Mart.). Food Science and Technology 28(2): 423-428.

Arévalo-Pinedo, A., Arévalo, Z. D. S., Beserra, N. S., et al. (2013). Development of flour babassu nut (orbygnia speciosa) based cereal bars. Brazilian Journal of Agro-indutrial Products 15(4): 405-411.

Bastos, G. A., Paulo, E. M., \& Chiaradia, A. C. N. (2014). Acceptability of potentially probiotic cereal bars. Braz. J. Food Technology 17(2): 113-120.

Botelho, L., Conceição, A., Carvalho, V. D. (2002). Caracterização de fibras alimentares da casca e cilindro central do abacaxi. Ciênc. Agrotéc 26(2): 362-67.

Brasil. (1978). Resolução CNNPA nº. 12, de 1978: Normas Técnicas Especiais. Diário Oficial da União.

Brasil. (2001). Resolução RDC nº 12, de 2 janeiro de 2001. Diário Oficial da República Federativa do Brasil. Seção 1: $45-53$.

Brasil. (2003). Resolução RDC no 360, de 23 de dezembro de 2003. Diário Oficial da República Federativa do Brasil.

Brasil. (2005). Instituto Adolfo Lutz. Métodos físico-químicos para análise de alimentos. (4a ed.).

Brito, I. P., Campos, J. M., Souza, T. F. L., et al. (2004). Elaboration and global evaluation of a home-made cereal. The CEPPA Bulletin 22(1): 35-45.

Bozza, A. F. O. (2004). Aproveitamento dos frutos o cerrado In. Anais do X Simpósio Ambientalista Brasileiro no Cerrado, Goiânia. CD-ROM.

Bueno, R. O. G. (2005). Características de qualidade de biscoito e barra de cereais ricos em fibra alimentar a partir de farinha de semente e polpa de nêspera. Dissertação (Mestrado em Tecnologia de Alimentos) Universidade Federal do Paraná, Curitiba.

Bueno, T. M., Schiassi, M. C. E. V., Souza, R. H., Carvalho, G. R., \& Queiroz, F. (2020). Effect of roasting and cooling on cereal bars developed with grape and jabuticaba residues. Research, Society and Development 9(11): e2879119783. 
Cecchi, H. M. (2003). Fundamentos teóricos e práticos em análise de alimentos. Editora da UNICAMP: (2nd ed.), editora da UNICAMP, 207.

Costa, J. M., Felipe, E. M., Maia, G. A., Brasil, I., \& Hernandez. (2007). Comparasion of physicochemical and chemical parameters of food powders obtained by pineapple residues. Revista Ciência Agronômica 38(2): 228-232.

Colussi, R., Baldin, F., et al. (2013). Acceptability and physicochemical stability of cereal bars elaborated based on oats and golden flaxseed. Braz. J. Food Tchnol 16(4): 293-300.

Chaves, M. C. V., Gouveia, J. P. G., et al. (2004). Caracterização físico-química do suco da acerola. Revista de Biologia e Ciências da Terra. Campina Grande, $\mathrm{PB}, 4(2)$.

Dutcosky, S. D. (2007). Sensory analysis of foods. Champagnat.

Fernandes, D., Freitas, J. B., Czeder, L. P., et al. (2010). Nutritional composition and protein value of the baru (Dipteryx alata Vog.) almond from the Brazilian Savanna. Journal of the Science of Food and Agriculture 90(10): 1650-1655.

Freitas, D. G. C., (2005). Desenvolvimento e Estudo da Estabilidade de Barras de Cereais de Elevado Teor Protéico e Vitamínico. Tese (Doutorado em Tecnologia de Alimentos) Faculdade de Engenharia de Alimentos, Universidade Estadual de Campinas, UNICAMP.

Freitas, J. B. (2009). Qualidade nutricional e valor proteico da amêndoa de baru em relação ao amendoim, castanha-de-caju e castanha-do-pará. Dissertação (Mestrado em Ciência e Tecnologia de Alimentos) - Escola de Agronomia e Engenharia de Alimentos, Universidade Federal de Goiás, Goiânia.

Freitas, J. B., \& Naves, M. M. V. (2010). Chemical composition of nuts and edible seeds and their relation to nutrition and health. Brasilian Journal of Nutrition 23(2): 269-279.

Freitas, D. G. C., \& Moretti, R. H. (2006). Caracterização e avaliação sensorial de barra de cereais funcional de alto teor proteico e vitamínico. Ciência e Tecnologia de Alimentos 26(2): 318-324.

Firestone, D. (Ed.). (2012). Official methods and recommended practices of AOCS. AOCS, 3(6), 1200.

Fonseca, R. S., Del, Santo, R., et al. (2011). Elaboração de barra de cereais com casca de abacaxi. Archivos Latinoamericanos de Nutrición 61(2): 216-223.

Fuentes, J. A. G., (1998). Que alimentos convêm ao coração? Higiene Alimentar, 12(53): 7-11.

Gomes, R. G., \& Penna, A.L.B. (2009). Características reológicas e sensoriais de bebidas lácteas funcionais. Ciências Agrárias 30(3): 629-646.

Guimarães, R. C. A., Vianna A. C, Machado A. A., et al. (2008). Caracterização Química da farinha desengordurada e obtenção do concentrado proteico de amêndoas de baru (Dipteryx alata Vog.). In: simpósio nacional sobre o cerrado. Brasília-DF.

Guimarães, M. M., \& Silva, M. S. (2009). Qualidade nutricional e aceitabilidade de barras de cereais adicionadas de frutos de murici-passa. Revista do Instituto Adolfo Lutz, 68(93): 426-433.

Gutkoski, L. C., Bonamigo, J. M. A., Teixeira, D. M. F., et al. (2007) Desenvolvimento de barras de cereais a base de aveia com alto teor de fibra alimentar. Food Science and Technology 27(2): 355-63.

Izzo, M., \& Niness, K. (2001). Formulating Nutrition Bars with Inulin and Oligofructose. Cereal Foods World 46(3): 102-105.

Jay, J. M. (2005). Microbiologia de alimentos. (6a ed.), Artmed.

Kobori, C. N., \& Jorge, N. (2005). Caracterização dos óleos de algumas sementes de frutas como aproveitamento de resíduos industriais. Ciência e agrotecnologia 29(5).

Lemos, D. M., Oliveira, E. N. A., Santos, D. C., et al. (2010). Composição fisíco-química de resíduos de abacaxi in natura e desidratado. Tecnologia \& Ciência Agropecuária 4(2): 53-56.

Lima, J. C. R., \& Costa, E. P. (2009). Processamento e valor nutricional de barras de cereais formuladas com polpa e amêndoa de baru. Trabalho de conclusão de curso (Graduação em Nutrição) - Faculdade de Nutrição, Universidade Federal de Goiás, Goiânia.

Lima, J. C. R., Freitas, J. B., Czeder, L. P., et al. (2010). Microbiological quality, acceptability and nutritional value of cereal bars formulated with baru pulp and almond. Boletim CEPPA 28(2).

Lima, M. M., Nune,s M. L., Aquino, L. C. L., et al. (2012). Desenvolvimento e caracterização físico-química, microbiológica e sensorial de barras de cereais adicionadas de quitosana e ômega-3. Scientia Plena, 8(3).

Louredo, E. G., Razia, J. R., Lima, L. P., et al. (2014). Biscoito tipo cookie enriquecido com baru. Revista Faculdade Montes Belos 7(1): 16-25.

Loverday, S. M., Hindmarsh, J. P., Creamer, L. K., et al. (2009). Physicochemical changes in a model protein bar during storge. Food Research International 42(7): 798-806.

Marques, T. R., Corrêa, A. D., \& Alves, A. P. C. (2015). Cereal bars enriched with antioxidant substances and rich in fiber, prepared with flours of acerola residues. Journal of Food Science and Technology 52(8): 5084-92.

Moscatto, J. A., Prudêncio-Ferreira, S. H., \& Hauly, M. C. O. (2004). Farinha de yacon e inulina como ingredientes na formulação de bolo de chocolate. Ciência e Tecnologia de Alimentos 24(4): 634-640. 
Monteiro, C. S., Carpes, S. T., Kalluf, V. H., Dyminski, D. S., Cândido, L. M. B. (2006). Evolução dos substitutos de gordura utilizada na tecnologia de alimentos. B. CEPPA, Curitiba, 24(2).

Oliveira, L. F, Nascimento, M. R. F., Borges, S. V., et al. (2002). Aproveitamento alternativo da casca do maracujá-amarelo (Passiflora edulis F. FLAVICARPA) para produção de doce em calda. Ciência e Tecnologia de Alimentos 22: 259-262.

Paiva, A. P., Barcelos, M. F. P., \& Pereiera, J. A. R., et al. (2012). Characterization of food bars manufactured with agroindustrial byproducts and waste. Ciência e Agrotececnologia, 36(3): 333-340.

Prado, I. D., Lallo, F. H., Zeoula, L. M., et al. (2003). Níveis de substituição da silagem de milho pela silagem de resíduo industrial de abacaxi sobre o desempenho de bovinos confinados. Revista Brasileira de Zootecnia 32(3): 737-744.

Ramos, A. S., Pereira, R. D., Andressa, I., Schmiele, M., \& Amaral, T. N. (2020). Development of cookies with fruit co-products. Research, Society and Development 9(10): e5799108918.

Rinaldi, M. M., Teixeira, L. P., Melo, R. A. C., et al. (2016). Desenvolvimento, Útil e Custo de Produção de Barra de Cereal Formulada à Base de Baru (Dypterix alata Vog.). Boletim de Pesquisa e Desenvolvimento, Embrapa Cerrados.

Rocha, L. S., \& Santiago, R. A. C. (2009). Implicações nutricionais e sensoriais da polpa e casca de baru (Dipterix alata vog.) na elaboração de pães. Revista Ciência e Tecnologia de Alimentos 29(4): 820-825.

Rodrigues, M. L., Fiorese, F., Júlio, T. S. K., et al. (2001). Controle de qualidade e análise centesimal de uma barra de cereal, comercializada na cidade de Cascavel, PR. Cultivando o Saber 4(1): 36-44.

Sano, S. M., Ribeiro, J. F., \& Brito, M. A. (2004). Baru: biologia e uso. Embrapa Cerrados. 52.

Sampaio, C. R. P. (2009). Desenvolvimento e estudo das características sensoriais e nutricionais de barras de cereais fortificadas com ferro. Dissertação de mestrado Universidade Federal do Paraná. Curitiba, PR, Brasil.

Sarantópoulos, C. L., Oliveira, L. M., \& Canavesi, E. (2001). Requisitos de conservação de alimentos em embalagens flexíveis. Campinas: CETEA/ITAL.

Silva, C. C. F. (2012). Qualidade de rapaduras enriquecidas com farelo de arroz extrusado e amêndoas de baru/amendoim torrados. Dissertação (Mestrado em Ciência e Tecnologia de Alimentos) Escola de Agronomia e Engenharia de Alimentos - UFG.

Silva, N., et al. (2010). Manual de métodos de análise microbiológica de alimentos e água. (4a ed.), Varela. 624.

Silva, F. A. S., \& Azevedo, C. A. V. (2009). Principal Components Analysis in the Software Assistant-Statistical Attendance. In: $7^{\text {th }}$ World Congress on Computers in Agriculture, Reno, Nevada, Published by: American Society of Agricultural and Biological Engineers.

Souza, A. N., \& Srebernich, M. S. (2010). Avaliação físico-química e determinação do valor nutricional de barras de cereais diet utilizando como agente ligante goma acácia. Anais do XV Encontro de Iniciação Científica da PUC.

Sousa, M. S. B., Vieira, L. M., Silva, M. J. M., et al. (2011). Caracterização nutricional e compostos antioxidantes em resíduos de polpas de frutas tropicais. Revista Ciência Agrotécnica 35(3): 554-559.

Sousa, R. S., Novais, T. S., Batista, F. O., \& Zuñiga, A. D. G. (2020). Sensory analysis of cookie developed with pineaplle shell flour (Ananas comosus (L.) Merril). Research, Society and Development, 9(4): e45942816.

Santos, G. G., Silva, M. R. D., \& Lacerda, B. C. L., et al. (2012). Acceptability and physicochemical quality of a sweet made from dipteryx alata vog. nuts. Agricultural Research in the Tropics 42(2): 159-165.

Stone, H., \& Sidel, J. L. (1993). Sensory evaluation practices. Academic Press.

Skliutas, A. R. (2002). Estudo do desenvolvimento de barra dietética de cereais e goiaba desidratada pelo processo de osmose à vácuo com utilização de frutooligossacarídeo. Dissertação (Mestrado em Tecnologia de Alimentos), Faculdade de Engenharia de Alimentos, Universidade Estadual de Campinas, UNICAMP.

Takemoto, E., Okada, I. A., Garbelotti, M. L., et al. (2001). Composição química da semente e do óleo de baru (Dipteryx alata Vog.) nativo do município de Pirenópolis, Estado de Goiás. Revista do Instituto Adolfo Lutz 60(2): 113-117.

Takeuchi, K. P., Sabadini, E., \& Cunha, R. L. (2005). Análise das propriedades mecânicas de cereais matinais com diferentes fontes de amido durante o processo de absorção de leite. Revista Ciência e Tecnologia de Alimentos 25(1): 78-85.

Teixeira, E., Meinert, E., \& Barbeta, P. A. (1987). Análise sensorial dos alimentos. UFSC, 182.

Togashi, M., \& Sgarbieri, V. C. (1994). Partial chemical characterization of baru fruit (Dipteryx alata, Vog.). Ciência e Tecnologia de Alimentos, Campinas. 14(1): 85-95.

Togashi, M., \& Sgarbieri, V. C. (1995). Nutritional assessment of baru seed protein and oil (Dypterix alata Vog.). Ciência e Tecnologia de Alimentos 15: 6669.

Vera, R., Soares, M. S., Jr, Naves. R. V., et al. (2009). Chemical characteristics of barueiro almonds (Dipteryx alata vog.). Naturally occurring in the cerrado of the state of Goiás, Brazil. Revista Brasileira de Fruticultura 1(1): 12-118. 